\title{
Research on the Training Mode of Applied Talents Based on Social Demand
}

\author{
Liu Lin \\ Jilin Institute of Traffic Technology, Changchun, Jinlin, China \\ Email: 4181861448@qq.com
}

Keywords: training mode; applied talents; social demand

\begin{abstract}
With the deepening of Chinese socialist market economy, the community's demand for management professionals is increasing. However, the management of students through the model and the social needs of the problem have been out of line. Especially in the context of economic restructuring, when the community's demand for management professionals will continue to adjust, the problem is more serious, and the need for talent training model changes. Therefore, it is necessary to explore the new requirements of the change of social demand in the new situation, and find out the shortcomings of the current personnel training mode, and further improve the current situation of personnel training in order to achieve the different periods of socio-economic structure changes brought about by personnel training the target requirements.
\end{abstract}

\section{Introduction}

With the development of economy, the demand for applied economic talents is growing. However, the analysis shows that economic graduates cultivated according to the traditional training methods can not meet the needs of employers. In the economic class of professional teaching and personnel training, still found the following problems: First, the development of training objectives in the lack of a sound system of research and research; the second is to cultivate the goal of achievement, the lack of clear and specific knowledge of personnel training Structural system and capacity requirements; Third, in the curriculum system design and training objectives to achieve the degree of disjoint, the design curriculum can not meet the requirements of the training objectives; Fourth, in the training process, teaching objectives and training objectives do not match, many courses teaching methods Still "indoctrination" mainly, can not play the students active classroom, teaching ineffective.

\section{Problems in the Training Mode of Management Talents}

The University of Economics and Management now has 11 undergraduate programs, including finance, international economics and trade, economic statistics, accounting, financial management, agroforestry management, information management and information systems, logistics management, human resources management, marketing. College based on "professional training objectives and social expertise of the professionals, the ability and quality structure requirements consistent with" the guiding ideology, year after year to improve undergraduate training programs, the professional training in the corresponding areas of the application of the type of compound professional talent for the training objectives, continue to transport quality personnel inside and outside the province. However, the current social demand for talent standards with the needs of Chinese economic development continue to adjust, the existing personnel training model still has some shortcomings.

The courses are divided into two categories, in-class and extra-curricular courses. The courses are divided into public courses, basic courses, professional courses and individual courses (professional elective courses), mainly to develop students' theoretical knowledge. Extracurricular courses mainly cultivate students' practical application ability, including practical teaching links and college students to develop two parts. Practical teaching links include education, military skills training, social practice and graduation practice and graduation thesis. The survey found that the professional structure of the curriculum in the design of the unreasonable phenomenon is more 
obvious, mainly for the emphasis on theory, light practice. According to the undergraduate training program published by the Academic Affairs Office of Hainan University, it can be seen that the proportion of courses in both domestic and foreign courses has been adjusted in recent years, but the proportion of class courses is far more than that of extracurricular courses. In the case of the latest "2015 Undergraduate Program", the number of courses offered by the courses should not exceed $16 \%$, and some less than $15 \%$ of the total. In the existing extracurricular curricula, the college students' quality development credits are not included in the student's personal assessment as a course credit, resulting in the fact that most students do not take this practical course seriously. In addition, the practice of teaching links include a large number of part of the course practice, and this part of the assessment is usually asked students to submit a course with the course of the course papers, its essence or to strengthen the student's theoretical knowledge, and did not achieve training The practical application of the purpose of students. Practice teaching links in the only rigid requirements need to be issued to prove the practice is part of the graduation practice. Graduation practice requires students to pay the practice of official seal of the internship certificate, but because of the lack of strict audit mechanism, coupled with the difficulty of identifying the authenticity of the internship is indeed relatively large and students often because of going abroad and other reasons not really required to participate in internship. To sum up, in terms of curriculum structure, the proportion of professional practice teaching is obviously insufficient, and the practical application ability of students is limited, so it is difficult to achieve the goal of cultivating applied talents.

Teaching content and teaching methods is a key part of the process of personnel training. The management of the teaching content and teaching methods are directly related to the ability to cultivate talents to find, think and solve problems, and to carry out the important tasks of cultivating and serving the enterprises and institutions to promote the development of regional economic development. The combination of teaching content in real terms helps to shorten the duration of the student's adaptation to the current social needs and quickly integrate into the post. Flexible teaching methods help students to think more about the way of thinking, improve the ability of students to use professional knowledge. Management of the current teaching content and methods of lack of innovation, it is difficult to meet the social needs of the management of talent. From the teaching content point of view, the management of the college teaching content is mostly based on the theoretical knowledge of the book, the lack of analysis of practical problems. Theoretical knowledge is important, but the ultimate goal of learning theory is to solve the problems in practical work, combined with practical problems on the basis of theoretical study, not only help to deepen the understanding of theoretical knowledge, but also help students to the transformation of theoretical knowledge into practical application. In addition, due to the management of professional teaching materials and more from abroad, knowledge theory is based on foreign developed economic market research found that the more teachers need to teach the theory at the same time combined with Chinese specific national conditions to be analyzed. From the teaching point of view, the teaching method is still basically follow the traditional teaching methods, that is, the individual instilling the students, students passive acceptance of the teaching form. This kind of teaching method has a very strong convergence, which is not conducive to cultivating students' personality difference and practical application ability to solve the problem. In the current social needs continue to adjust the background, personalized, differentiated application of talent is more likely to come to the fore, get the appreciation of the employer. Students' learning results are usually reflected by the examination results, the examination results are both a study of student learning, but also the incentive for students to learn. In principle, the final exam results accounted for $70 \%$, usually $30 \%$ of the results. Usually refers to the students usually learning attitude, attendance, experiment or practice, classroom discussions and so on, as well as the usual test and mid-term assessment of the comprehensive assessment of the results. In accordance with the results of the end of the assessment method can be divided into examination classes and examination courses. The course does not require a final exam, and the student usually submits a course-related essay at the end of the course. The teacher gives the final grade of the course according to the quality of the paper. Examination 
course refers to the students at the end of the need to participate in the final exam, the examination results are the end of the course results.

Management of the current professional assessment system is single, pay attention to the assessment of the theoretical knowledge of students, while ignoring the assessment of its application ability. From the "2015 undergraduate training program" found that the basic courses and courses of economics and management courses for most of the examination courses, due to the usual low scores, and usually based on the attendance of students given, the evaluation of the professional quality of students is the basic indicators of students of the final exam results. Even the examination class, the end of the paper usually does not need students to investigate the actual, just by means of China knowledge network, library materials and other resources to complete the library. In addition, the study also found that the management of students in the professional courses are mostly concentrated in the third year, and the majority of test courses, students face greater test pressure, it is difficult to have time to learn the theoretical knowledge into practical application. It can be seen that the school's assessment of students focus on the degree of mastery of student knowledge to check, and can not reflect the comprehensive ability of a student. Based on the background of this assessment, students can only be recognized by increasing the theoretical knowledge, thus ignoring the cultivation of their own practical application ability. Management and management is the application of professional, and based on this assessment methods to cultivate the talent for the knowledge of the inheritance of narrow caliber talent, can not effectively promote the comprehensive ability of students, especially the practical application of training.

\section{Suggestions on the Mode of Cultivating Applied Talents}

To cultivate the application talents who meet the needs of the society and meet the needs of the market, we must improve the application ability of the students to solve the practical problems. The school should enrich the content of the practical teaching courses and increase the proportion of the credits in the general course while strict teaching management, to ensure the effective use of practical teaching links. Under the premise of ensuring the system and coherence of knowledge, we should reduce the course of public courses and basic courses, construct practical skills training, practice investigation, innovation and entrepreneurial activities and so on. In the course content arrangement should keep up with the needs of market development, flexible adjustment of professional courses to ensure that students can apply their knowledge. Due to the limited range of professional courses and professional courses, the setting of professional elective courses is particularly important for cultivating students' personal interests and future employment intent. Therefore, the content of professional elective courses should be based on the current social needs. Hainan University is the only one in Hainan Province 211 University, the sea graduates throughout the various units in Hainan Province, the school can use their own advantages to the management of professional involved in the enterprises and institutions, especially enterprises, the issue of curriculum questionnaire, comprehensive sort out the units we think that the most practical professional course is elective course of each specialty. At the same time, you can invite well-known entrepreneurs in Hainan to participate in elective courses and entrepreneurs can be based on the enterprise's entry standards to students in the very practical recommendations to stimulate students' interest in learning, but also to a certain extent, directly to solve professional training and social needs out of touch.

\section{Conclusion}

Through the research on the training model of economic talents oriented to the goal of training, and through the close development of today's economic development, students have made interest in economic teaching, not only theoretically improved, but also improve the students' economy Operational skills, to understand the dynamics of today's economy. Therefore, the reform is necessary, but also achieved very good results. The talent training model has been applied in the fields of finance, international trade and other economic specialties. The interest of classmates in 
the classroom has increased than in the past. In their papers, they have felt their understanding of economic dynamics. In the discussion, they felt that they could use the knowledge they had learned to solve the real economic problems.

\section{References}

[1] Zhang Yi, Tang Youming, Sun Guibin, Wang Ping, Zhang Bingrong. Practice and research on curriculum achievement evaluation based on learning achievement [J]. Education and Teaching Forum. 2017 (39)

[2] Guo Si. Ventralized course diagnosis method based on graduation requirement [J].China Education Information. 2017 (14)

[3] Yang Yan, Ma Yongqiang, Tang Huijia, Yang Hui. Several key issues to improve the quality of graduation requirements evaluation [J].Computer Education. 2017 (06)

[4] ZHANG Tao, CAO Hai-lan, LI Hui. Evaluation of graduation degree scheme based on attribute topology [J]. Digital Design. 2016 (01)

[5] CUI Guo-ting, ZHANG Zhong-xin, REN Guang-yue. Evaluation of graduation requirement of food science and engineering specialty [J].Heilongjiang Education. 2016 (06)

[6] Zhou Jingmei. Study on the Application of Goal Completion in the Course of "Accounting Basis" Course Evaluation [J].Human Resources Development. 2015 (20) 